\title{
IMPLEMENTATION OF MARBLE WASTE AS AGGREGATE MATERIAL RIGID PAVEMENT
}

\author{
Candra Aditya $\square$ \\ Department of Civil Engineering ${ }^{l}$ \\ chandra172.ch@gmail.com,candra@widyagama.ac.id \\ Dafid Irawan \\ Department of Civil Engineering ${ }^{l}$ \\ Silviana Silviana \\ Department of Industrial Engineering ${ }^{l}$ \\ ${ }^{1}$ University of Widyagama Malang \\ $35 \mathrm{Jl}$. Borobudur, Mojolangu, Kec. Lowokwaru, Kota Malang, Indonesia, 65142
}

$\triangle$ Corresponding author

\begin{abstract}
The rigid pavement is used for the pavement with soft ground conditions (subgrade). On the other hand, in recent years, marble waste for civil construction has been widely used to substitute conventional materials such as fine and coarse aggregate in concrete. This study aims to optimize marble sand waste as a substitute for river sand aggregates on concrete pavements. This research creates innovation in the production of rigid pavement. The study used an experimental method to test the raw material, namely fine aggregate (river sand and marble sand) and rigid pavement testing, with various variations in the material's composition, including loading, strain, and concrete slab stress tests. The use of marble sand as a substitute for river sand affects the compressive strength of concrete. The maximum compressive strength of $34.67 \mathrm{~N} / \mathrm{mm}^{2}$ occurs at $60 \%$ marble sand content. Calculation of the optimum level of marble sand by the regression method yielded $48.90 \%$ with an average compressive strength of $32.37 \mathrm{~N} / \mathrm{mm}^{2}$. In terms of strain, rigid pavement concrete slabs with $60 \%$ marble sand content showed the best performance among all specimens. The stretch is relatively small so that it is not so fluctuating, the flexibility is relatively small, and the stiffness is the highest. The strain character tends to be compressive so that the dependence on reinforcement will decrease. Dynamically at the shock load, the three concrete slabs are quite good and very far from resonance in both the traffic service load frequency and the large shock load. Rigid pavement concrete slabs with a marble sand content of $40 \%$ show the best performance because they are damping faster and have less tension. Statically, rigid pavement concrete slabs with a marble sand content of $60 \%$ are the best.
\end{abstract}

Keywords: rigid pavement, marble waste, concrete slab, compressive strength, concrete slab strain, concrete slab stiffness, concrete slab flexibility, shock load, concrete aggregates, traffic service load.

DOI: $10.21303 / 2461-4262.2021 .001932$

\section{Introduction}

Population growth and the increasing number of vehicles will significantly influence the increase in road infrastructure needs. The road is a land transportation infrastructure that is very important with the movement of people and goods. Generally, rigid pavement is used for pavement on soft ground conditions (subgrade). The pavement on soft soil requires a larger pavement thickness so that the structural load also increases. Soils in natural condition with low to moderate density tend to experience a large deformation under repeated vehicle loads. Pavement serves to provide a flat and smooth surface for riders and protect land formations against the adverse effects of weather changes [1]. The most common problems found in the rigid pavement are the occurrence of cracks and the spreading mechanism. The pavement fatigue cracking was caused by (repeated load) traffic, which caused the stress to be lower than the concrete pavement's tensile strength [2].

On the other hand, using various kinds of waste as a substitute for civil construction aggregates has been widely studied. The existence of global issues regarding the environment also adds to the importance of waste utilization. Waste in the form of marble sand, which is the lead- 
ing waste from the marble stone industry's processing, has been widely used as a substitute for river sand aggregates in the manufacture of construction materials. The research results prove that marble waste material has the potential to continue to be developed as an alternative material in the manufacture of building materials because, in addition to the availability of marble waste, it is also proven that it can be used as a substitute for materials that can improve the quality of building materials.

Many kinds of research on marble waste as a functional material for construction have been carried out. Replacement of sand with marble sand on concrete tiles [3] resulted in an increased bending load of concrete tiles by $327.86 \mathrm{~N}(29.26 \%)$ from standard concrete tiles ( $0 \%$ onyx sand). The replacement of sand with onyx sand in paving blocks [4] increased the compressive strength of paving blocks, the composition of 1 PC:6 PsO increased by $147.72 \mathrm{~kg} / \mathrm{cm}^{2}$ (64.05\%), compared to the compressive strength of paving blocks of the composition of 1 PC:6 Ps ( $\%$ onyx sand). Replacing river sand with marble sand and Portland cement with marble waste powder in the manufacture of concrete roof tiles and paving blocks [5] resulted in a decrease in weight and flexural strength but still feasible and meets the requirements of SNI 0096:2007.

Road pavement planning has the main parameters related to traffic aspects, subgrade conditions, design age, and pavement material used. Based on the Road Pavement Design Manual issued by the Directorate General of Highways (2013), a road pavement structure can consist of several pavement layers with various materials (5]. In general, the pavement structure consists of a surface layer, a foundation layer, and a subgrade layer, which is located above the subgrade. Meanwhile, the technical requirements and criteria for road technical planning are based on the Regulation of the Minister of Public Works (2011) [6, 7].

Of course, a strong pavement structure must be supported by subgrade conditions that have a high carrying capacity. If the original soil condition has a carrying capacity with CBR of less than $6 \%$, then the subgrade must be repaired. Improvement of the subgrade should strive so that the CBR of the subgrade is more than $6 \%$ and must be strong with the wheels' weight. If the subgrade still has a low bearing capacity below the CBR of $6 \%$, the pavement structure will quickly suffer damage [8]. The pavement structure consists of several layers of pavement with various materials. In general, the pavement structure can be seen in Fig. 1.

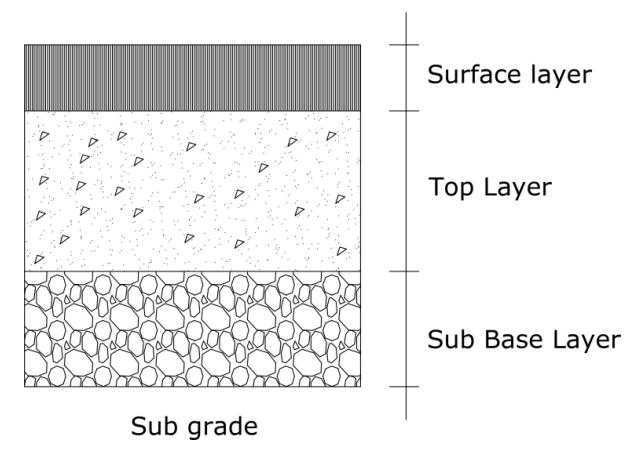

Fig. 1. The structure of the pavement layer (Source: Cement concrete pavement planning SNI Pd T-14-2003)

In general, road pavement consists of several types of pavement layers that are arranged from bottom to top, as follows:

- sub-grade soil layer;

- sub-base course;

- top foundation layer (base course);

- surface course.

There are four types of cement concrete pavement: Non-reinforced cement concrete pavement, cement concrete pavement with reinforcement, continuous cement concrete pavement with reinforcement, and pre-stressed cement concrete pavement $[9,10]$. A typical cement concrete pavement structure is shown in Fig. 2. 
In cement concrete pavement, the pavement bearing capacity is mainly obtained from the concrete slab. Nature, bearing capacity, and uniformity of the subgrade significantly affect the durability and strength of cement concrete pavements. The factors that need to be considered are compaction moisture content, density, and moisture content changes during the service period. Cement concrete slabs have a reasonably rigid nature and can spread loads over a wide area and produce low stresses in the layers underneath. If a high level of comfort is required, the cement concrete pavement surface can be coated with a layer of asphalt mixture $5 \mathrm{~cm}$ thick (Pd T-14-2003) [11, 12].

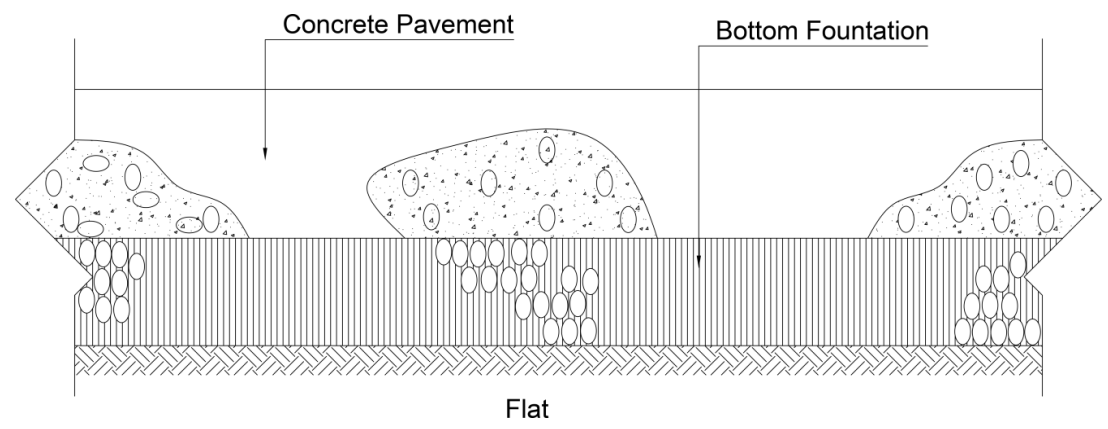

Fig. 2. Typical cement concrete pavement structure

Research on concrete slabs made of marble sand as the rigid pavement is expected to produce an understanding of the behaviour of rigid pavement concrete slabs made from marble waste from the aspect of stiffness and attenuation of the concrete slabs by comparing normal concrete slabs and concrete slabs made from marble waste sand.

The effect of using marble sand on a concrete slab will affect the quality of normal concrete. This will be very useful in the use of waste materials as an aggregate substitute for conventional materials that have been used as concrete aggregates.

This research creates innovations in the production of rigid pavement made from marble waste which has high economic value and is environmentally friendly. This study aims to optimize the use of marble sand waste as a substitute for river sand aggregate in concrete pavement. In addition, it is expected that the use of marble sand waste can improve the quality of building materials.

\section{Material and methods}

\section{1. Material}

The marble sand is sand ( $2 \mathrm{~mm}, 4 \mathrm{~mm}$ ) and powder (passes 200 filters). Marble waste is used for fine aggregate with a mixture of $30 \%$ powder, $30 \%$ marble sand $2 \mathrm{~mm}, 40 \%$ marble sand $4 \mathrm{~mm}$. Before being used as a fine aggregate material for concrete, it must first be carried out an aggregate gradient analysis of marble sand to determine the appropriate marble waste aggregate size. The marble sand used is sand from processed marble waste in the Campurdarat District, Tulungagung Regency, Indonesia.

\section{2. Methods}

\section{2. 1. Design of rigid pavement concrete slabs}

Rigid pavement consists of 3 (three) concrete slabs measuring $3 \times 4 \times 0.3 \mathrm{~m}$ without reinforcement with a thickness of $25 \mathrm{~cm}$. Concrete slabs are made with a mixture of marble waste in the sand at $0 \%$ (without marble sand), $40 \%$, and $60 \%$. The position of the 3 specimens of rigid pavement concrete slabs (0\%, $40 \%, 60 \%$ marble sand) can be seen in Fig. 3.

Three rigid pavement specimens were lined up. Test object number 1 is rigid pavement with $0 \%$ marble sand content. Test object number 2 is a rigid pavement with a marble sand content of $40 \%$ and specimen number 3 is a rigid pavement with a marble sand content of $60 \%$. These three types of specimens were cast in situ and made lined up according to the sequence to make it easier to test with truckloads passing above the rigid pavement. 

Number 4
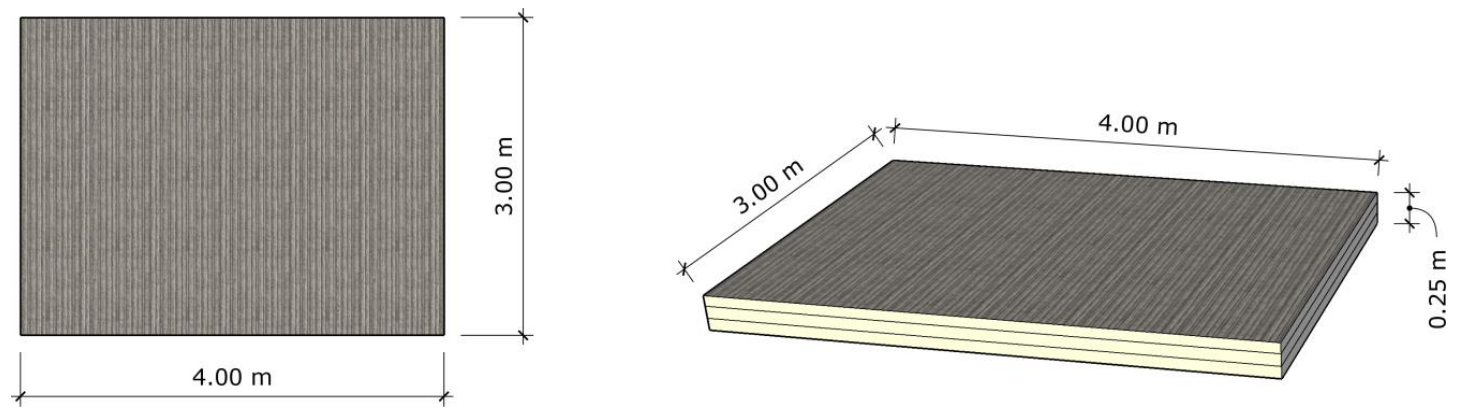

$a$
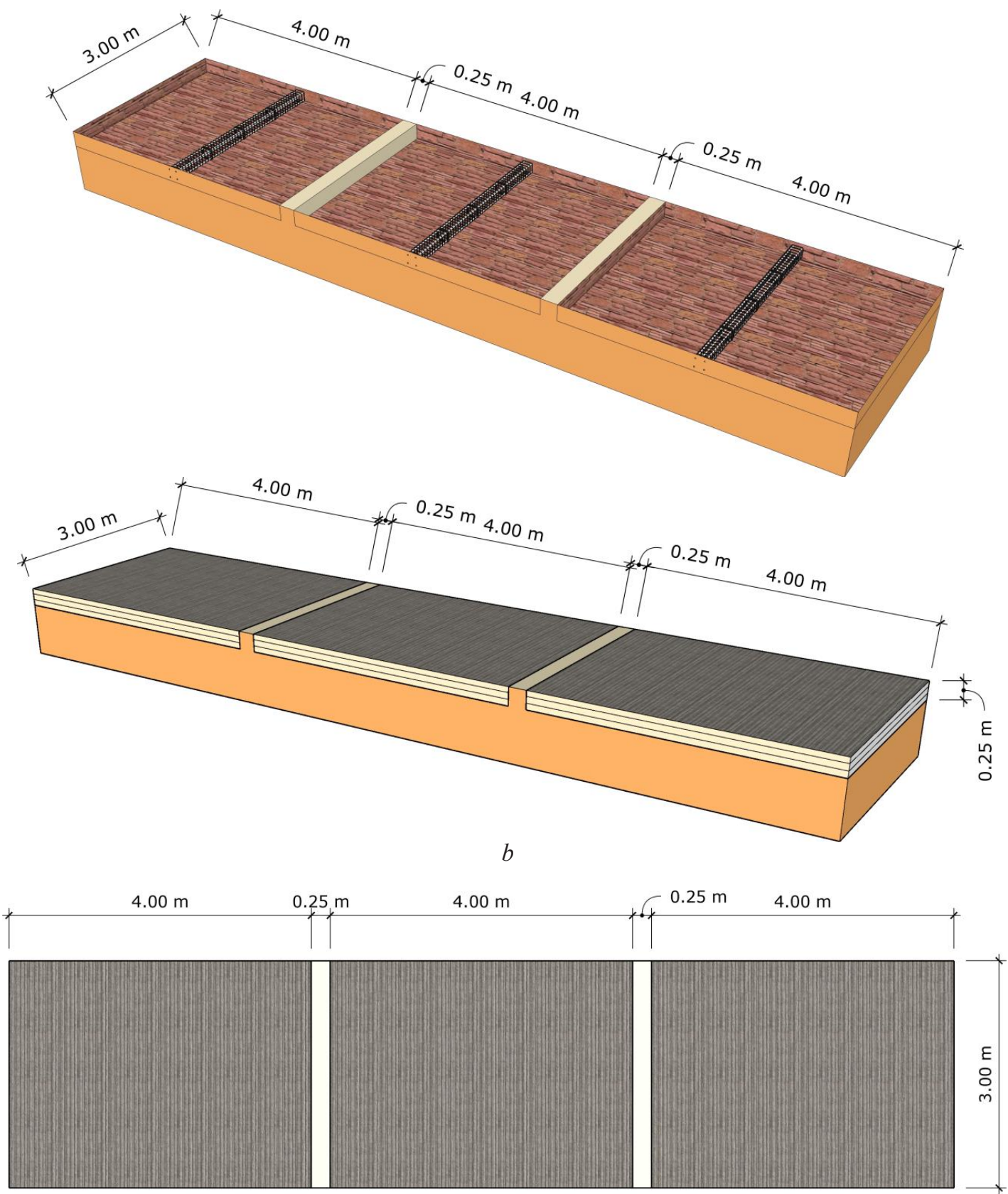

Fig. 3. Design of rigid pavement concrete slab specimen; $a$-Dimensions of the rigid pavement concrete slab specimen; $b$ - Dimensions and positions of 3 rigid pavement concrete slab specimens; $c$ - The sequence position of the rigid pavement concrete slab specimen number 


\section{2. 2. Experimental setup}

To determine the effect of using marble sand as fine aggregate material and determine the marble waste mixture's composition. It is fine aggregate material on the most optimal rigid pavement. Several tests were carried out in the laboratory and the field. The test begins with a preliminary test to test the physical elements of marble waste, including specific gravity, absorption, fine modulus, and gradation.

To determine the behaviour of concrete with marble waste on the rigid pavement, 1:1 scale test object is made, namely a concrete slab measuring $3 \times 4 \times 0.25 \mathrm{~m}$, which is cast in place with variations of concrete slabs with $0 \%$ marble sand, concrete slabs with $40 \%$ marble sand and concrete slabs with $60 \%$ marble sand. This dimension follows the field's original size, namely one lane minima $2.75 \mathrm{~m}$ and a truck length of $4 \mathrm{~m}$. Meanwhile, the thickness is the minimum thickness for rigid pavement.

Concrete slabs as rigid pavements are placed on the ground as a subgrade. Soil (subgrade) is used as elastic support with a CBR value of $6 \%$.

The test object was made of 3 types:

1) rigid pavement concrete slab $0 \%$ marble waste;

2) rigid pavement concrete slab $40 \%$ marble waste;

3) rigid pavement concrete slab sample $60 \%$ marble waste.

The consideration of the percentage of marble waste is the composition of concrete with marble waste that produces the highest compressive strength, split tensile strength and flexural strength in testing cylindrical specimens' strength.

For each specimen, 4 pieces of strain gauges are installed for the top 2 positions and 2 carrying positions. This strain gauge is installed to determine the strain, stress, vibration, and deflection data on the test object during the loading test.

Fig. 4 show the test object in the form of a rigid pavement concrete slab is placed on the ground with a CBR above $6 \%$. The three specimens were lined up according to the sequence of concrete with marble sand content from $0 \%$ to $60 \%$. In the initial stage, the preparation of the concrete slab specimen is carried out before casting, namely in the form of plastic installation, installation of strain gauge on tie bars and dowel bars. After that, casting is done on the concrete slab specimen and maintenance is carried out for 28 days before testing.

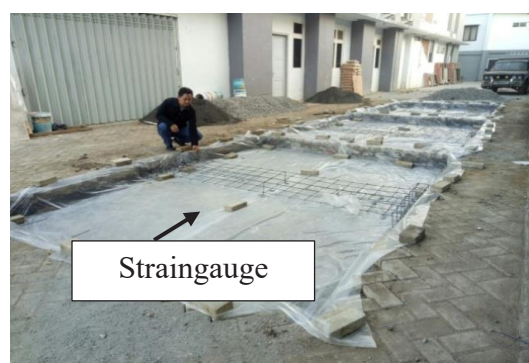

$a$

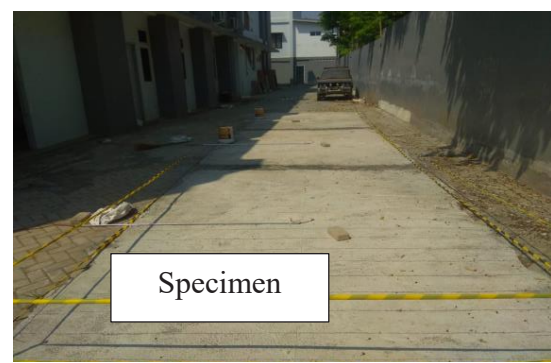

$b$

Fig. 4. The process of making Rigid Pavement concrete slab; $a$ - the rigid pavement concrete slab before casting (installation of plastics, strain gauge and reinforcement); $b$ - the rigid pavement concrete slab after casting

\section{2. 3. Rigid pavement concrete slab testing}

The Rigid Pavement concrete slab testing is 28 days by testing the vibration of traffic loads by being traversed by trucks. The concrete slabs are also given a shock load with Non-Destructive Testing (NDT) testing to determine the test object's stress, strain, vibration, and deflection. The testing process for rigid pavement concrete slabs from the preparation of the NDT tool to the provision of truckloads can be seen in Fig. 5.

Testing of rigid pavement concrete slab specimens is carried out at the age of more than 28 days with NDT (Non-Destructive Testing) testing, namely testing the vibration of traffic loads and their interference with the shock load on the concrete slab to determine the stress, strain, vibration and deflection of the test object. 


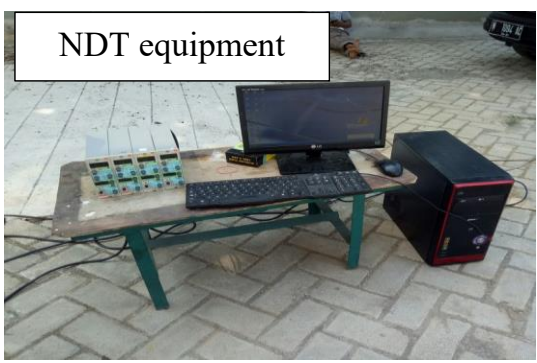

$a$

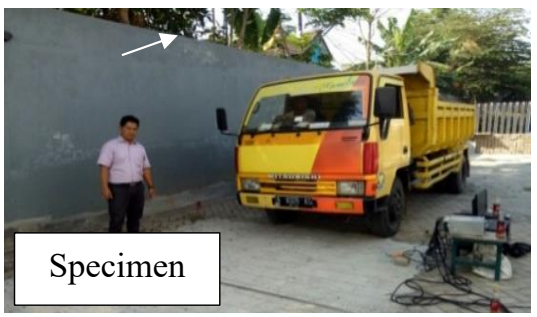

$c$

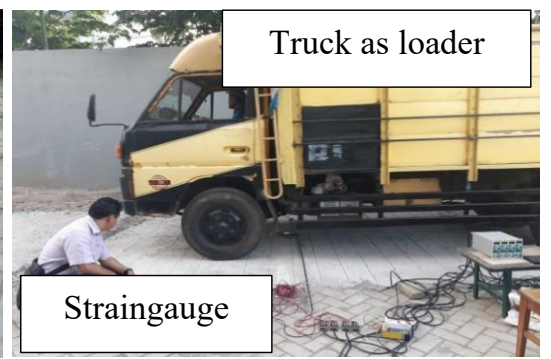

$b$

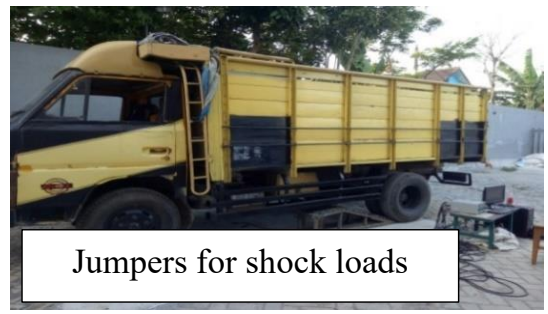

$d$

Fig. 5. Testing Rigid Pavement Concrete slabs using Non-Destructive Testing (NDT): $a$ - NDT testing equipment; $b$ - trucks as loaders on rigid pavement specimens; $c$ - load on the rigid pavement concrete slab through trucks passing above the rigid pavement; $d$ - a jumper that is placed on the specimen to be traversed by the truck as a shock load provider

\section{Results and discussion}

3. 1. Marble waste as fine aggregate material

Data on the results of marble waste sand testing, which include water content, specific gravity, volume weight, absorption/absorption, and modulus of fineness, the results can be seen in Table 1.

Table 1

Results of Testing for Marble Waste Sand and River Sand

\begin{tabular}{|c|c|c|c|c|}
\hline \multirow{2}{*}{ Type of testing } & \multirow{2}{*}{ Unit } & \multicolumn{2}{|c|}{ Test Results } & \multirow{2}{*}{$\begin{array}{c}\text { ASTM } \\
\text { Standard }\end{array}$} \\
\hline & & Lumajang sand & Marble waste sand & \\
\hline Fine grain modulus & $\%$ & 3.10 & 2.90 & $1.50-3.80$ \\
\hline Grading zone & - & 3 (slightly fine sand) & 2 (medium sand) & $1-4$ \\
\hline Saturated surface specific gravity (bulk specific gravity) & $\mathrm{gr} / \mathrm{cm}^{3}$ & 2.61 & 2.53 & $2.50-3.00$ \\
\hline Apparent specific gravity & $\mathrm{gr} / \mathrm{cm}^{3}$ & 2.72 & 2.83 & - \\
\hline Absorption & $\%$ & 2.53 & 6.84 & - \\
\hline Water content & $\%$ & 1.53 & 0.84 & - \\
\hline Weight (solid) & $\mathrm{gr} / \mathrm{cm}^{3}$ & 1.414 & 1.678 & - \\
\hline Sludge content & $\%$ & 3.70 & - & $<5$ \\
\hline
\end{tabular}

The test results of marble sand and river sand (Lumajang) are suitable for use as fine aggregate for concrete because they have entered the ASTM standard. When compared to the test results between marble sand and river sand (Lumajang), marble sand has higher absorption than river sand. This means that marble sand has higher water absorption ability. The water content of marble sand is lower than that of river sand. This means that marble sand contains less water than river sand. The specific gravity and bulk density between the two types of sand are relatively the same.

\section{2. Testing of Cylindrical Concrete Compressive Strength}

Testing compressive strength on cylindrical specimens with a diameter of $15 \mathrm{~cm}$ and a height of $30 \mathrm{~cm}$ is carried out using a Compression Testing Machine. 
The test results of the average compressive strength of concrete for each composition of river sand replacement with marble waste sand can be seen in Fig. 6.

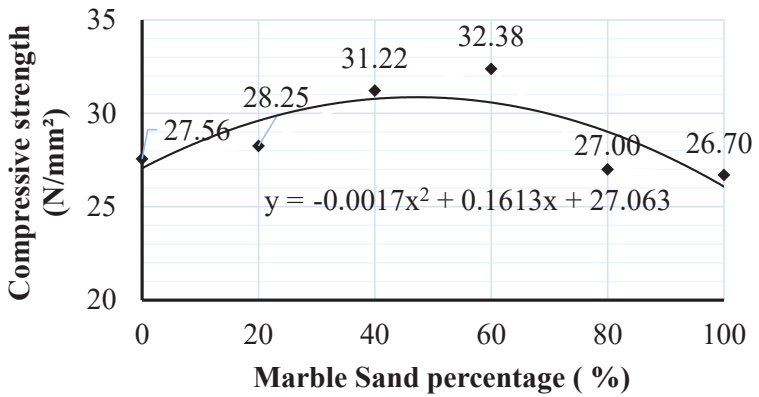

Fig. 6. The relationship between marble sand content and the average compressive strength of concrete

Fig. 6 shows a change in the concrete's compressive strength due to the replacement of river sand with marble sand. At $20 \%, 40 \%$, and $60 \%$ marble sand content, there was an increase in the concrete's compressive strength, but at $80 \%$ and $100 \%$ marble sand content, there was a decrease in the concrete's compressive strength. The change in compressive strength due to marble use can be determined by reducing the change in each mixture of marble sand content to the compressive strength of $0 \%$ marble sand content.

Fig. 7 shows the average compressive strength test of $20 \%$ marble content of $28.25 \mathrm{~N} / \mathrm{mm}^{2}$ with a difference of $0.69 \mathrm{~N} / \mathrm{mm}^{2}$ from $0 \%$ marble so that the compressive strength increased by an average of $2.51 \%$ of the average compressive strength of marble content $0 \%$. The average compressive strength of $40 \%$ marble content is $31.22 \mathrm{~N} / \mathrm{mm}^{2}$ with a difference of $3.66 \mathrm{~N} / \mathrm{mm}^{2}$ or an average compressive strength increase of $13.27 \%$ from the average compressive strength of $0 \%$ marble content. The average compressive strength of $60 \%$ marble content was $32.38 \mathrm{~N} / \mathrm{mm}^{2}$ with a difference of $4.82 \mathrm{~N} / \mathrm{mm}^{2}$ or an increase in the average compressive strength of $17.49 \%$ from the average compressive strength of $0 \%$ marble content. The average compressive strength of $80 \%$ marble content was $27.00 \mathrm{~N} / \mathrm{mm}^{2}$ with a difference of $-0.56 \mathrm{~N} / \mathrm{mm}^{2}$ or experienced a decrease in $-2.03 \%$ from $0 \%$ marble content. The average compressive strength of $100 \%$ marble content was $26.70 \mathrm{~N} / \mathrm{mm}^{2}$ with a difference of $-0.86 \mathrm{~N} / \mathrm{mm}^{2}$ or experienced a decrease in $-3.13 \%$ from the average compressive strength of $0 \%$ marble content. The maximum average compressive strength achieved by fine aggregated concrete marble waste is $32.38 \mathrm{~N} / \mathrm{mm}^{2}$ at $60 \%$ marble content with an increase of $4.82 \mathrm{~N} / \mathrm{mm}^{2}$ or $17.49 \%$ of the average compressive strength of $0 \%$ marble content.

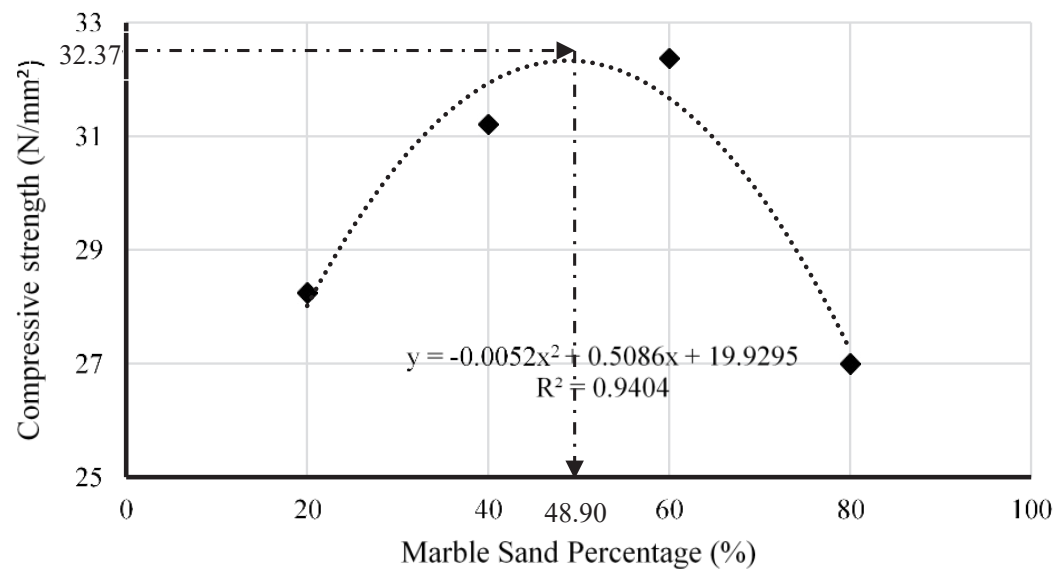

Fig. 7. Content of marble sand that produces optimum compressive strength

Fig. 7 also shows that the optimum marble content can be found by the regression method. A graph of the relationship between marble content and the average compressive strength can 
be drawn from the average compressive strength results. Based on the graph above the regression line produces the equation: $y=-0.0052 x^{2}+0.5086 x+19.9295 ; R^{2}=0.9404$. To get the optimum compressive strength results, the above equation is reduced to $-0.0104 x+0.5086=0$, so that $x=0.5086 / 0.0104=48.90 \%$. For $48.90 \%$, marble content yields an average compressive strength of $32.37 \mathrm{~N} / \mathrm{mm}^{2}$.

\section{3. Testing traffic load vibrations and interference with shock loads}

Testing the specimens is 28 days by testing the vibration of traffic loads and their interference with the concrete slab's shock load, namely by testing the NDT (Non-Destructive Testing) to determine the stress, strain, vibration, and deflection of the test object.

Fig. 8 shows the zoom of the strain on concrete slab 1 (0\% marble sand) in microstrain $\left(10^{-6}\right)$ taken randomly in a medium time (random medium time) of 41 seconds as a test load of trucks running slowly.

It can be seen in the picture that the maximum strain recorded by the strain gauge after entering the NEC AS1803 strain amplifier shows that the concrete slab in traffic loads still has a deficient strain, namely $-0.005 \cdot 10^{-6}$, which is far below the maximum strain of melting steel or crushed concrete, is $0.002-0.003$.

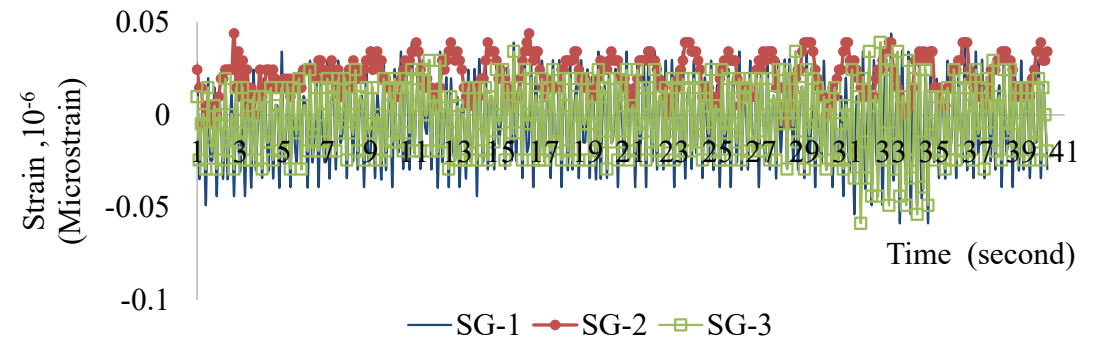

Fig. 8. Strain in the $1^{\text {st }}$ test (concrete slab $0 \%$ marble sand) random medium time of $-0.005 .10^{-6}$

The SG-1 and SG-3 strain gauges show the upper concrete slab's strain value attached to the right and left sides. The lowest values consistently show -0.06 and are in the same range, namely -0.06 to +0.02 microstrain. The tensile section, namely the SG-1 strain gauge installed at the base close to the ground, shows a value that tends to be tensile or positive, namely 0 to +0.047 .

Likewise, in Fig. 9, the second test of concrete slab 1 ( $0 \%$ marble sand) is still in the medium time range (random medium time), 32 seconds. The maximum amount of strain is around $+0.07 \cdot 10^{-6}$, which is also still very low. Over a longer range, it can be seen that the strain average tends to show a positive value.

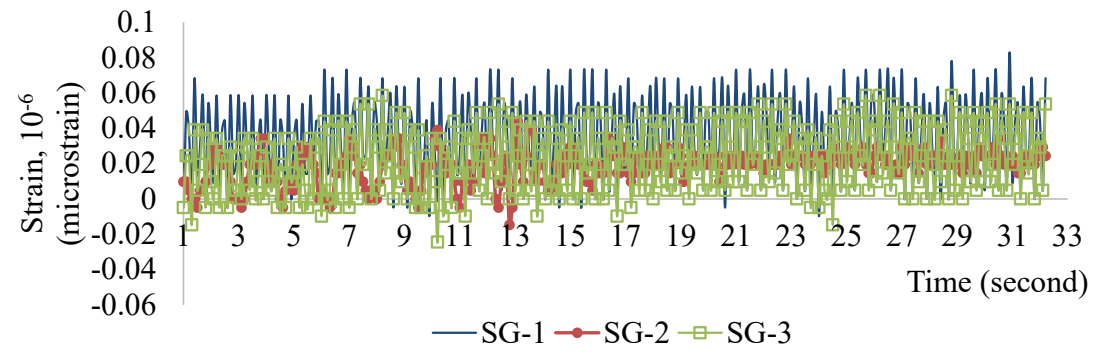

Fig. 9. Strain in the $2^{\text {nd }}$ test (concrete slab $0 \%$ marble sand) random medium time of $0.07 .10^{-6}$

For the short duration (random short time), the $3^{\text {rd }}$ test for concrete slab 1 ( $0 \%$ marble sand) is 26.9 seconds, shown in Fig. 10. The amount of maximum strain begins to appear higher, which is around $+0.06 \cdot 10^{-6}$, but this is still very low compared to 0.003 .

Whereas in Fig. 11, the frequency of the $1^{\text {st }}$ impact load test for concrete slab $1(0 \%$ marble sand) shows. The highest strain spike is achieved by a frequency of $0.04 \mathrm{~Hz}$ below the base frequency of $0.8 \mathrm{~Hz}$ from the concrete slab frequency table, so there will be no resonance. 


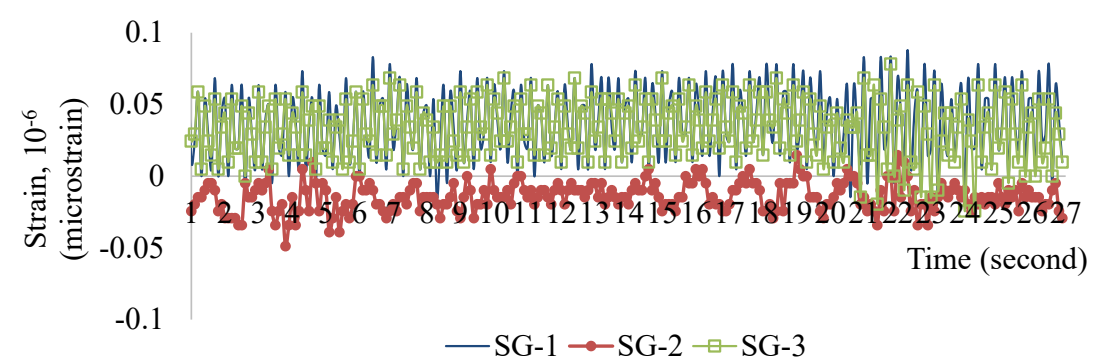

Fig. 10. Strain in the $3^{\text {rd }}$ test (concrete slab $0 \%$ marble sand) random medium time of $+0.06 .10^{-6}$

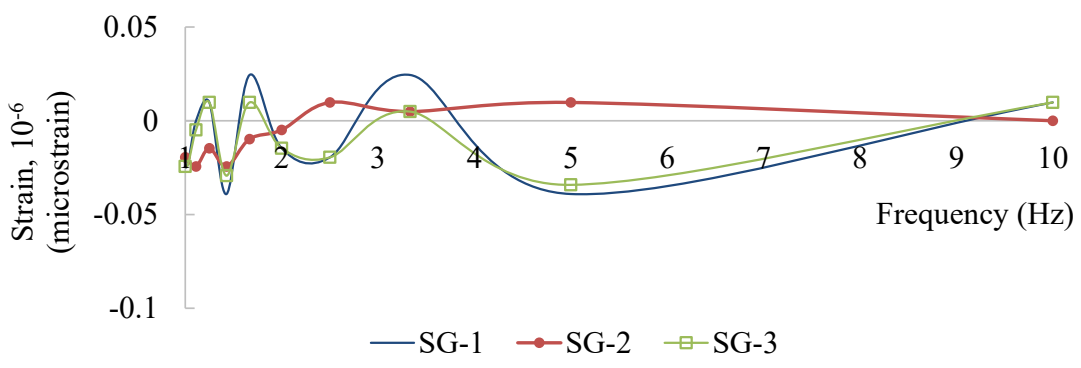

Fig. 11. Frequency of first dynamic impact testing for concrete slab 1 (0\% marble sand) of $0.04 \mathrm{~Hz}$

The 1st test for concrete slab 2 (40\% marble sand) was repeated to benchmark. The data can be seen in Fig. 12, showing the microstrain's strain $\left(10^{-6}\right)$, taken randomly in a slightly longer time but still at the random medium time, namely 56.1 seconds. The maximum amount of strain is $+0.065 \cdot 10^{-6}$, which is still very low compared to the maximum strain of melted steel or crushed concrete, which is $0.002-0.003$.

The positive strain on SG-2 and SG-3 indicates the concrete floor's elastic properties, which can show a positive reflective effect. The maximum value of the negative strain on SG-1 and SG-4 is also negative, namely $-0.043 \cdot 10^{-6}$, which is still very low compared to the maximum strain of melted steel or crushed concrete, which is $0.002-0.003$.

Whereas in the medium duration (random medium time), which is 49.7 seconds, shown in Fig. 13, the maximum strain size starts to appear, sometimes it is slightly lower, which is around $+0.02 \cdot 10^{-6}$, which is also still very low compared to the value of 0.003 .

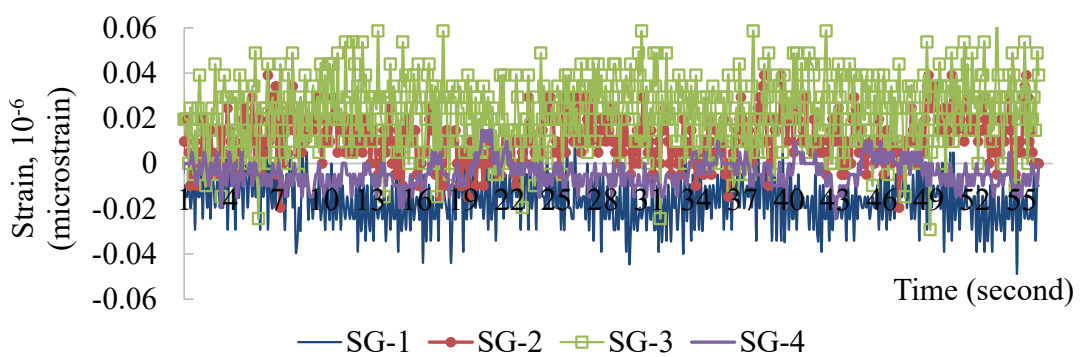

Fig. 12. Strain in the $1^{\text {st }}$ test (concrete slab $40 \%$ marble sand) random medium time of $+0.065 .10^{-6}$

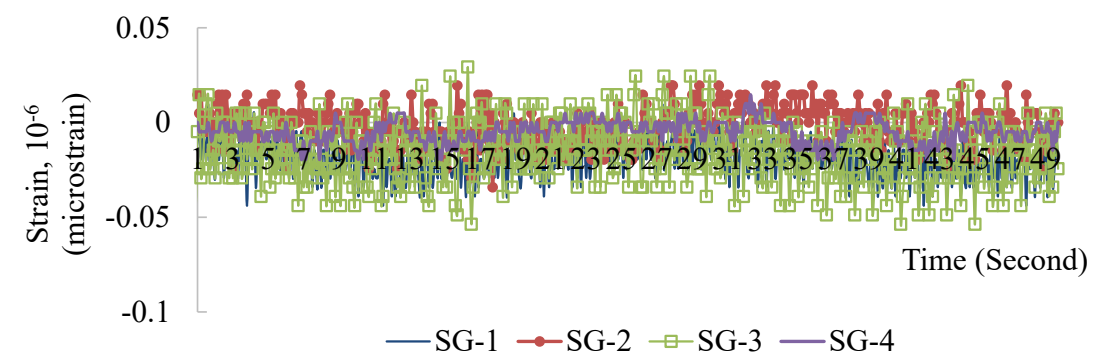

Fig. 13. Strain in the $2^{\text {nd }}$ test (concrete slab $40 \%$ marble sand) random medium time of $-0.04 .10^{-6}$ 
In the short duration (random short time), the $3^{\text {rd }}$ test for concrete slab-2 (40\% marble sand) is 33.9 seconds, shown in Fig. 14. The amount of maximum strain starts to appear somewhat higher, which is around $+0.048 \cdot 10^{-6}$, which is also still very low compared to the value of 0.003 .

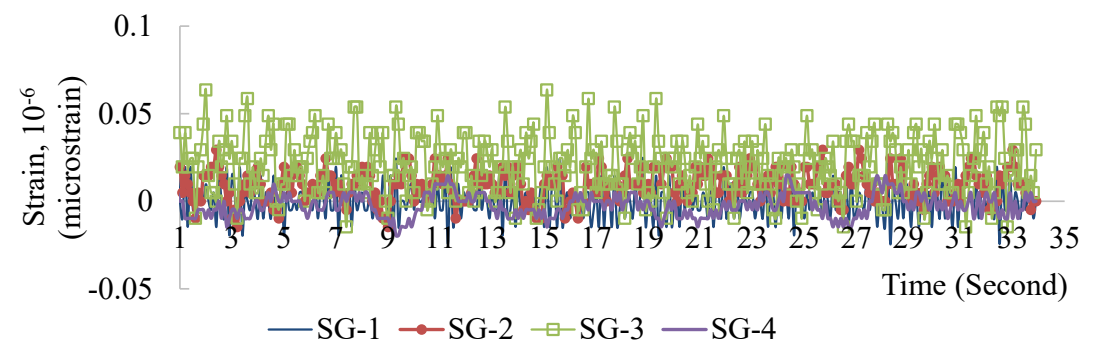

Fig. 14. Strain in $3^{\text {rd }}$ test (concrete slab $40 \%$ marble sand) random medium time of $+0.06 .10^{-6}$

Fig. 15 shows the second shock load test frequency for concrete slab 2 (concrete slab $40 \%$ marble sand). The highest strain spike is achieved by a frequency of $0.042 \mathrm{~Hz}$ below the fundamental frequency of $0.8 \mathrm{~Hz}$ so that there will be no resonance.

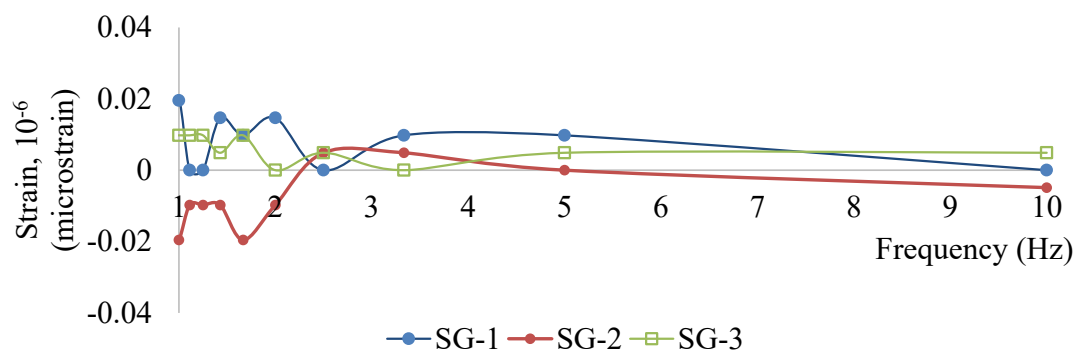

Fig. 15. Frequency of shock testing (dynamic impact) for concrete slab 2 (40\% marble sand) the random long time is $0.042 \mathrm{~Hz}$

Test 1 for concrete slab 3 (60\% marble sand) shows that the strain is taken randomly in a slightly shorter time (random short time), namely 28.6 seconds. The maximum strain magnitude in Fig. 16 is about $+0.047 \cdot 10^{-6}$ to $-0.035 \cdot 10^{-6}$ is still very low compared to the maximum strain of melting steel or crushed concrete, which is $0.002-0.003$.

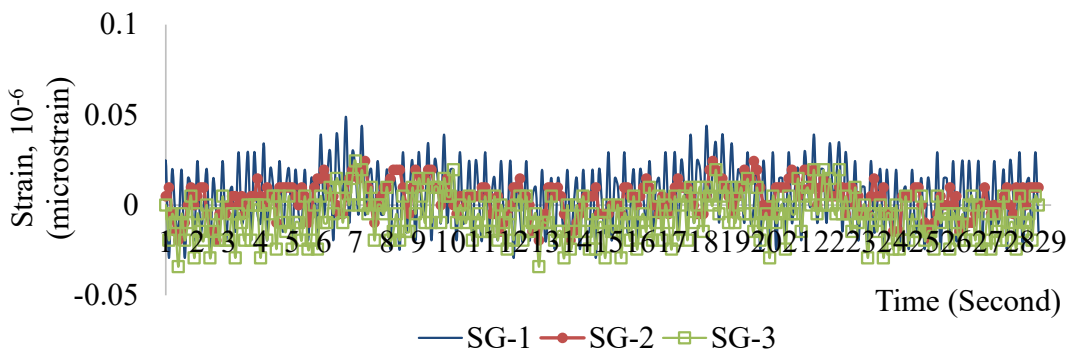

Fig. 16. Strain in the $1^{\text {st }}$ test (concrete slab $60 \%$ marble sand) random short time is $-0.02 \cdot 10^{-6}$

When observed in Fig. 17, the frequent strain ranges or intervals are in the stretch range between -0.02 to $+0.025 \cdot 10^{-6}$, which is very safe in terms of limit strain.

Whereas in the short duration (random short time), the 3rd test for the 3rd concrete slab (60\% marble sand) is 24.7 seconds, shown in Fig. 18. The maximum strain size starts to appear dominant press, which is around $-0.047 \cdot 10^{-6}$, which is also still very low compared to the value of 0.003 .

Fig. 19 shows the frequency of the shock load test. The highest strain spike is achieved by a frequency of $0.0426 \mathrm{~Hz}$ below the fundamental frequency of $0.8 \mathrm{~Hz}$ so that there will be no resonance. 


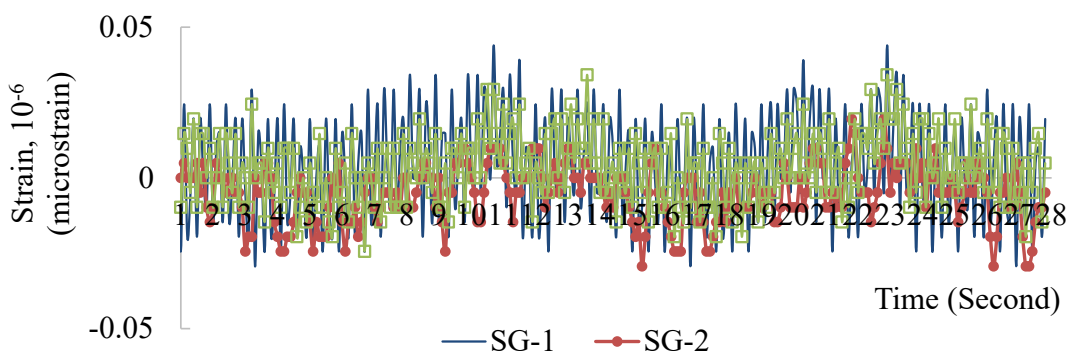

Fig. 17. Strain in the $1^{\text {st }}$ test (concrete slab $60 \%$ marble sand) random short time of $+0.0354 \cdot 10^{-6}$

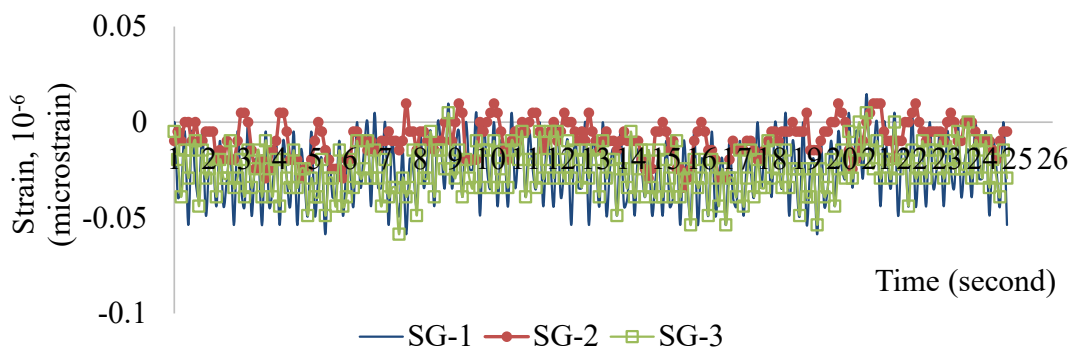

Fig. 18. Strain in the $3^{\text {rd }}$ test concrete slab-3 random short time of $-0.047 \cdot 10^{-6}$

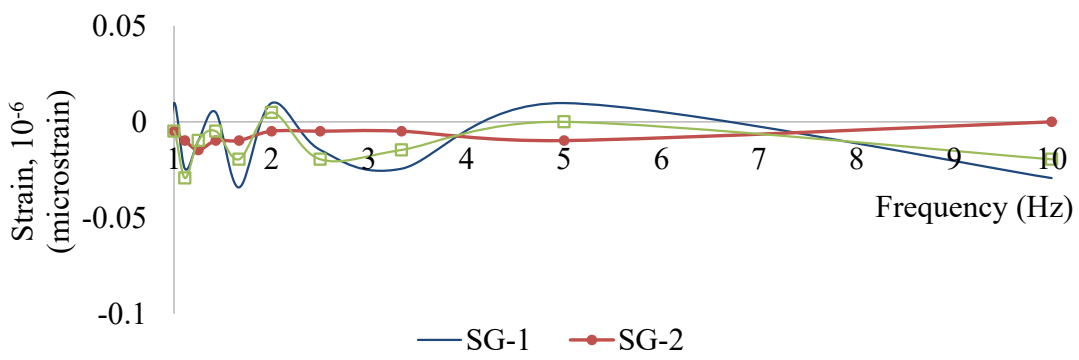

Fig. 19. Frequency of shock testing (dynamic impact) For concrete slab 2 (40\% marble sand), random short time is $0.04262 \mathrm{~Hz}$

From the test results on the rigid pavement cast in situ floor concrete slab and tested by non-destructive test (NDT) against the dynamic shock load of the truck wheels with a concentrated load of 2 tons through the jumped ramp, the results show that concrete slab 1 (concrete slab with $0 \%$ marble sand) showed the lowest performance of all specimens. It can be seen from the large enough strain that ranges from about $+0.06 \cdot 0^{-6}$ to $-0.04 \cdot 10^{-6}$. The tension range fluctuates considerably, indicating concrete slab 1 is too flexible, and the stiffness is relatively low. Also, the strained character tends to be tensile, so that the dependence on reinforcement is quite large.

While concrete slab 2 (concrete slab with $40 \%$ marble sand) shows somewhat better than concrete slab-1, this can be seen from the moderate strain, which is around $+0.05 \cdot 10^{-6}$ to $-0.035 \cdot 10^{-6}$. The tension range fluctuates sufficiently, which indicates that concrete slab-2 is moderate in flexibility and stiffness is higher than concrete slab-1. Also, the tensile character tends to be tensile, and the compression is somewhat balanced so that the dependence on reinforcement will be reduced.

Meanwhile, slab 3 (concrete slab with $60 \%$ marble sand) showed the best performance among all specimens. This can be seen from the relatively small strain, that is, the strain interval that often is in the stretch range between $+0.02 \cdot 10^{-6}$ to $-0.045 \cdot 10^{-6}$. The tension range is not so fluctuating, which means that the 3-concrete slab flexibility is relatively small, and the stiffness is the highest. Also, the strained character tends to be compressive, so that the dependence on reinforcement will decrease.

In terms of shock load dynamics, the three concrete slabs are quite good and very far from resonance in both the traffic service load frequency and the large shock load. The best is the con- 
crete slab 2, which is faster to damp and less grip. So the concrete slab-3 is statically the best, and against shock loads dynamically, the concrete slab 2 is better than all.

The limitation of this study is marble waste in the form of sand which is used as a substitute for river sand in concrete as pavement on the rigid pavement. The rigid pavement is a type of Joint Unreinforced Plain Concrete Pavement (JPCP).

The direction of the development of this research is to produce a planning and design model of road pavement as a solution for the use of waste to contribute to road development problems, both local and national scale.

\section{Conclusion}

The use of marble sand as a substitute for river sand affects the compressive strength of concrete. The maximum compressive strength of $34.67 \mathrm{~N} / \mathrm{mm}^{2}$ occurs at $60 \%$ marble sand content. The regression method calculated the optimum marble sand content from equation $y=-0.0052 x^{2}+0.5086 x+19.9295$ to produce a marble sand content of $48.90 \%$ with an average compressive strength of $32.37 \mathrm{~N} / \mathrm{mm}^{2}$.

In terms of strain aspect, rigid pavement concrete slabs with $0 \%$ marble sand content show the lowest performance compared to rigid pavement concrete slabs with $40 \%$ and $60 \%$ marble sand content. The strain is quite large and fluctuates greatly, indicating the concrete slab is too flexible, and the stiffness is relatively low. Strain tends to be tensile, so the dependence on reinforcement is quite large. Rigid pavement concrete slabs with $40 \%$ marble sand content show better performance. The tensile character tends to be tensile, and the compression is somewhat balanced so that the dependence on reinforcement is reduced. Rigid pavement concrete slabs with $60 \%$ marble sand content showed the best performance among all specimens. The stretch is relatively small so that it is not so fluctuating, the flexibility is relatively small, and the stiffness is the highest. The strain character tends to be compressive so that the dependence on reinforcement will decrease.

Dynamically, at the shock load, the three concrete slabs are quite good and very far from resonance in both the traffic service load frequency and the large shock load. Rigid pavement concrete slabs with a marble sand content of $40 \%$ show the best performance because they are damping faster and have less tension. Statically, rigid pavement concrete slabs with a marble sand content of $60 \%$ are the best.

\section{Acknowledgment}

We are grateful to the Directorate of Research and Community Service (DRPM), Deputy for Strengthening Research and Development of the Ministry of Research and Technology of Higher Education (Kemenristekdikti), who funded those who contributed to the implementation of this research.

\section{References}

[1] Hardiyatmo, H. C. (2002). Mekanika Tanah I, Edisi Kedua. Universitas Gadjah Mada.

[2] Sebayang, I. R. (2013). Monitoring dan Evaluasi Perkerasan Kaku. Kementerian PU Badan Penelitian dan Pengembangan Pusjatan. Bandung. Available at: http://perpustakaan.pusjatan.pu.go.id/repositori/system/files/10\%20NI\%20Monitoring\% 20\%26\%20Evaluasi\%20Perkerasan\%20Aspal\%20Rev.pdf

[3] Aditya, C. (2010). Pengaruh Penggunaan Limbah Pasir Onyx sebagai Bahan Pengganti Pasir Pada Kuat Lentur, Rembesan dan Penyerapan Air Genteng Beton. Jurnal Ilmiah Widya Teknika, 18 (2), 7-13.

[4] Aditya, C. (2012). Pengaruh penggunaan limbah pasir onyx sebagai substitusi pasir terhadap kuat tekan, penyerapan air dan ketahanan aus paving block. Jurnal Ilmiah Widya Teknika, 20 (1), 18-24. Available at: http://publishing-widyagama.ac.id/ ejournal-v2/index.php/widyateknika/article/view/3/3

[5] Aditya, C., Halim, A., Putri, C. F. (2014). Waste Marble Utilization from Residue Marble Industry as a Substitution of Cement and Sand within Concrete Rooftile Production. International Journal of Engineering Research, 3 (8), $501-506$. doi: https://doi.org/10.17950/ijer/v3s8/806

[6] Prayitno, P., Rulianah, S., Zamrudy, W., Susilo, S. H. (2021). An analysis of performance of an anaerobic fixed film biofilter $\left(\mathrm{AnF}_{2} \mathrm{~B}\right)$ reactor in treatment of cassava wastewater. Eastern-European Journal of Enterprise Technologies, 1 (10 (109)), 6-13. doi: https://doi.org/10.15587/1729-4061.2021.225324 
[7] Kementerian PUPR (2017). Manual Desain Perkerasan Jalan (Revisi 2017). Dirjen Bina Marga. Jakarta.

[8] Peraturan Menteri Pekerjaan Umum (2011). Persyaratan Teknis Jalan Dan Kriteria Perencanaan Teknis Jalan.

[9] Austroads (1992). Pavement Design. A Guide to the Structural Design of Road Pavements. Design of New Rigid Pavements.

[10] Diklat Perkerasan Kaku. Kementerian PUPR (2017). Pengembangan Infrastruktur Wilayah. Jakarta.

[11] Pd T-14-2003: Perencanaan Perkerasan Jalan Beton Semen (2003). Departemen Permukiman dan Prasarana Wilayah. Jakarta.

[12] Buku Informasi: Melaksanakan Pekerjaan Perkerasan Jalan Beton (2011). Kementerian Pekerjaan Umum. Badan Pembinaan Konstruksi, Pusat pembinaan Kompetensi dan pelatihan Konstruksi. Jakarta.

Received date 22.11.2020

Accepted date 04.06.2021

Published date 31.05.2021
(C) The Author(s) 2021

This is an open access article under the Creative Commons CC BY license

How to cite: Aditya, C., Irawan, D., Silviana, S. (2021). Implementation of marble waste as aggregate material rigid pavement. EUREKA: Physics and Engineering, 4, 76-88. doi: https://doi.org/10.21303/2461-4262.2021.001932 